\title{
INFLUENCE OF ANAESTHETICS ON RHEOLOGY OF HUMAN BLOOD
}

\author{
H. Ben-Zion Aronson, F.F.A.R.C.S.I., PaUl R. Levesque, M.D., \\ Stanley Charm, M.S., SC.D., and Benjamin Etsten, M.D. $†$
}

THE IMPORTANCE of the rheological properties of blood in maintaining circulatory homeostasis during health and disease has recently been emphasized. ${ }^{1-5}$ Flow rates of liquids were first experimentally related by Poiseuille in 1842 to pressure difference and tube geometry. ${ }^{6}$ In 1860 , Hagenbach showed that when a homogenous (Newtonian) fluid flows in a vessel, the tangential stress (shear stress) between the adjacent laminae as they slip over each other is directly proportional to the velocity gradient (shear rate) which develops across the adjacent laminae. ${ }^{\text {? }}$

However, in a non-homogenous (non-Newtonian) liquid such as blood, $2-5,8$ it has been shown that the shear stress is not a linear function of shear rate in the region of low shear rate. Blood viscosity is markedly increased at low rates of shear (Fig. 1). It is at the very low shear rates that the yield stress and cell aggregation ${ }^{4,9}$ exert a major effect on the viscometry of blood (Fig. 2).

Yield stress is the measurement of the stress required to set static blood in motion and appears to be related to breaking down these aggregates of red cells, which are fibrinogen-linked. Yield stress, therefore, becomes of great importance to flow patterns in the microcirculation where low shear rates are present, particularly when reduction of blood velocity occurs. Previous reports ${ }^{10,11}$ concerning influences of anaesthetics on blood viscosity are difficult to evaluate because these studies were made at relatively high shear rates and the yield stress was not considered.

The purpose of the present study was to determine the effects of halothane, cyclopropane, and methoxyflurane upon the blood and plasma viscometry as determined by shear rate-shear stress relationship, yield stress, and Casson viscosity under rigidly controlled conditions.

\section{Matertals and Methods}

The fresh blood (type $\mathrm{O}, \mathrm{Rh}^{+}$) used in this study was obtained from healthy white male volunteers. Five hundred ml. of blood was collected from each subject into the transfusion bag which contained 2,250 units of heparin buffered with

-Department of Anesthesiology, Tufts University School of Medicine and New England Medical Center Hospitals, and Department of Physiology, Tufts University School of Medicine. This work was supported by grants $\mathrm{HE} 01711$ and $\mathrm{HE} 08783$ from the National Institutes of Health, U.S. Public Health Service.

†Dr. Aronson is Research Fellow in Anesthesiology, New England Medical Center Hospitals, Boston, Mass., and Lecturer in Anesthetics at Hadassah Hebrew University, Jerusalem, Israel; Dr. Levesque is Assistant Professor of Anesthesia; Dr. Charm is Associate Professor of Biomedical Engineering; and Dr. Etsten is Professor of Anesthesiology. 


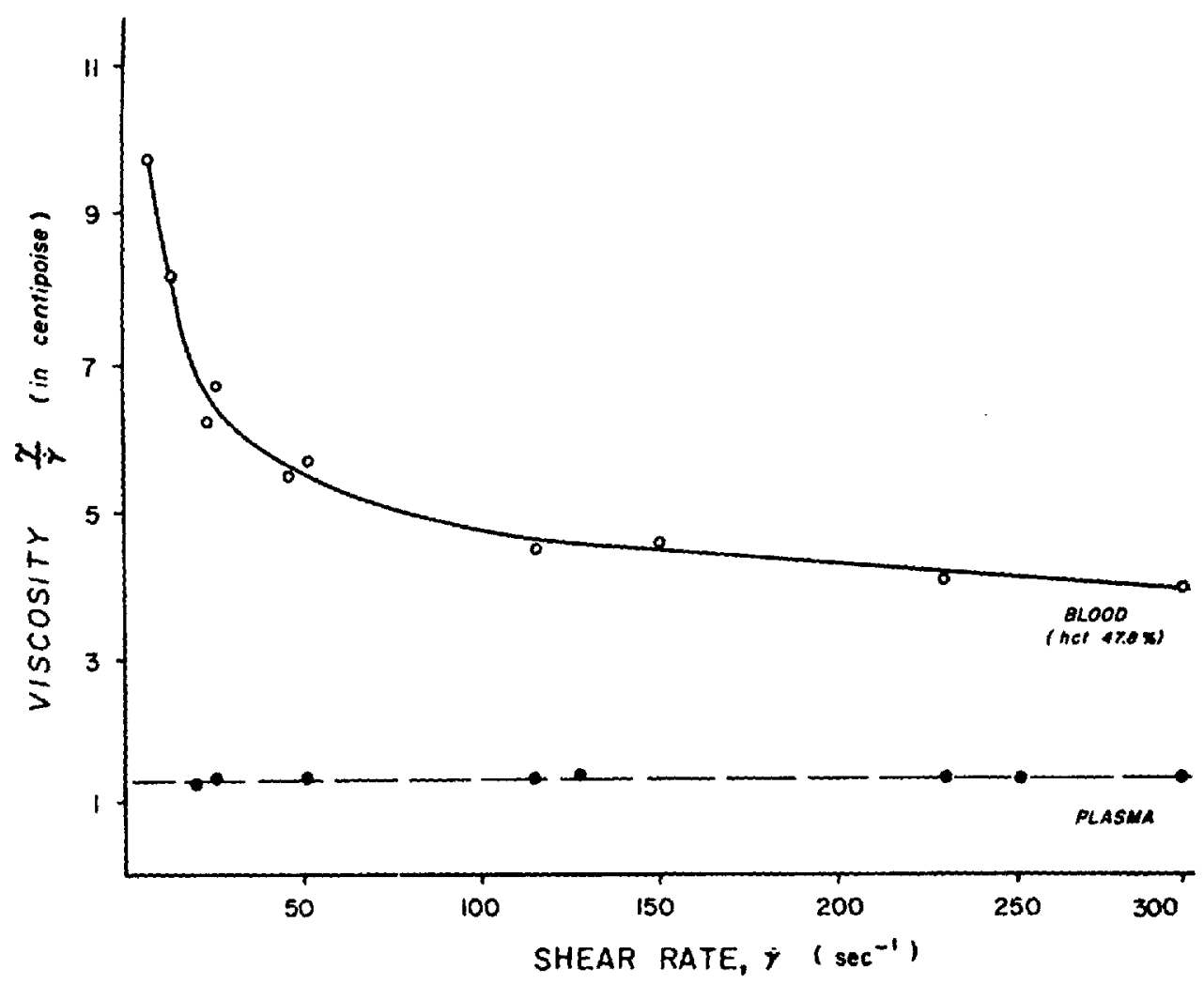

Figure 1. Viscosity-shear rate diagram of blood and plasma. Ordinate: apparent viscosity, $\tau / \dot{\gamma}$, in centipoise; abscissa: shear rate, $\dot{\gamma}$, in sec. -1 . Note that viscosity increases markedly at lower rates of shear.

sodium phosphate ( 4.5 units per $\mathrm{ml}$. blood). The method of saturating blood with anaesthetic agents having normal blood $\mathrm{pH}$ values and gas tensions was similar to that described previously. ${ }^{12}$ In brief, the blood was transferred to a $2 \mathrm{~L}$. flask and equilibrated with a humidified gas mixture of 3.4 per cent $\mathrm{CO}_{2}$ in $\mathrm{O}_{2}$ at a flow rate of $800 \mathrm{ml}$. per minute. The flask and humidifier were kept in a water bottle at constant temperature $\left(27^{\circ} \mathrm{C}\right.$. and $\left.37^{\circ} \mathrm{C} .{ }^{*}\right)$. The equilibration usually took from 45 to 75 minutes with gentle rotation of the flask in order to increase the functional surface area. The blood gas tensions and $\mathrm{pH}$ were measured every 15 minutes by appropriate electrodes (Radiometer Gas Monitor with $\mathrm{pH} \mathrm{M} \mathrm{27,}$ Copenhagen). In some experiments, the concentrations of $\mathrm{CO}_{2}$ and $\mathrm{O}_{2}$ in the gas mixture were altered in order to obtain the normal values for the blood gas tensions and $\mathrm{pH}\left(\mathrm{Po}_{2}:>200 \mathrm{~mm} . \mathrm{Hg}, \mathrm{PcO}_{2}: 40 \pm 4 \mathrm{~mm}\right.$. $\mathrm{Hg}$, and $\mathrm{pH}: 7.40 \pm$ $0.04)$. For measurements of the rheological properties, the control blood samples were taken from the flask into vacutainers containing no anticoagulant.

The remaining portion of blood was then divided into two parts. Each part of blood was transferred to a $2 \mathrm{~L}$. flask and saturated with a specific anaesthetic

The experiments nos. $\mathrm{C} 6, \mathrm{C} 7, \mathrm{C} 9$, and $\mathrm{Cl} 0$ were equilibrated at $37^{\circ} \mathrm{C}$., and the others were done at $27^{\circ} \mathrm{C}$, since metabolic acidosis occurred less frequently at the lower temperature. 
$\sqrt{\left(\text { dyne } / \mathrm{cm}^{2}\right)}$

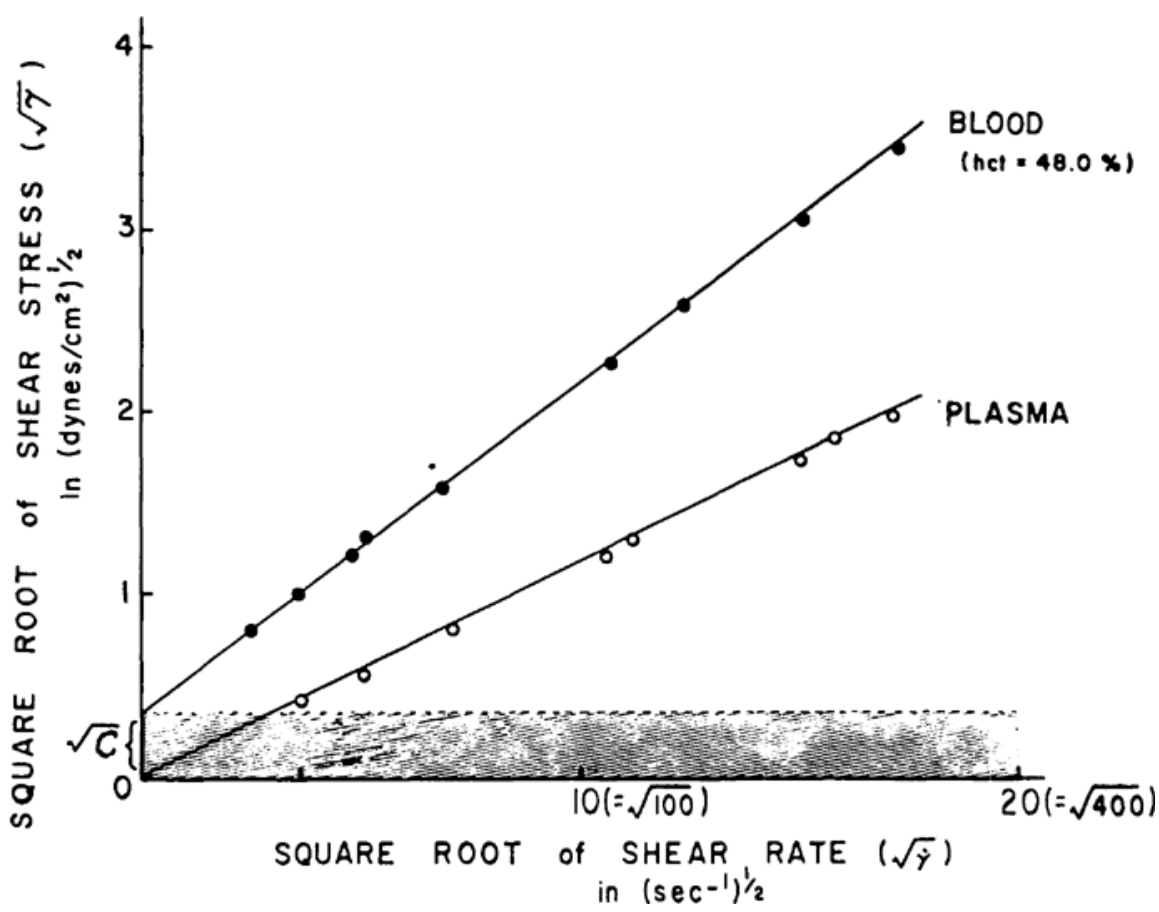

Figure 2. Square root of shear stress, $V \tau$, versus square root of shear rate, $V \dot{\gamma}$, for whole blood and plasma. The ordinate intercept is the square root of blood yield stress, $\sqrt{ } C$, in $V$ (dynes $/ \mathrm{cm}^{2}$ ). The slope of the straight line is the square root of the Casson's viscosity.

agent. Different concentrations of an anaesthetic agent were used at the same time for each part of blood in order to eliminate the possible effect on viscometry due to prolonged exposure of blood to the anaesthetic agent. Cyclopropane was added to the gas mixture from a Foregger anaesthesia machine; halothane or methoxyflurane (penthrane) were added using appropriate vaporizers in series. At the end of a one to two hour period of gas equilibration, the gas flow was discontinued and the flasks were sealed.

Final blood anaesthetic concentrations ranged from 4 to $57 \mathrm{mg}$. per cent for cyclopropane, 4 to $65 \mathrm{mg}$. per cent for halothane, and 8 to $143 \mathrm{mg}$. per cent for methoxyflurane.

Samples were taken in duplicate into vacutainers from the flasks for measurements of the Casson blood viscosity, blood yield stress, apparent plasma viscosity, blood and plasma anaesthetic concentrations before and after the viscometric procedures, haematocrit, haemoglobin contents in plasma and blood gas tensions, and $\mathrm{pH}$. Data were discarded when values of blood $\mathrm{PCO}_{2}, \mathrm{Po}_{2}$, and $\mathrm{pH}$ were not within the normal ranges. In addition, plasma protein concentrations were measured in nine studies. Haematocrit was measured by centrifugation for five minutes at a speed of 11,500 r.p.m. in a micro-capillary centrifuge (Model MB 
with \#275 head: International Equipment Co., Needham Heights, Mass.). The haemoglobin content of the plasma samples was measured by the cyanmethaemoglobin method. ${ }^{13}$

The shear stress-shear rate relationship for whole blood and plasma samples was determined in a series of three cone plate Wells-Brookfield Micro Viscometers which cover the shear rate range from $6.75 \mathrm{sec}^{-1}$ to $1,500 \mathrm{sec}^{-1}$ (Brookfield Engineering Labs Inc., Stoughton, Mass.). The operational principle of the cone plate viscometers has been described elsewhere. ${ }^{14}$ The calibration of the viscometers was made before each study with the use of standard oils (National Bureau of Standards, Washington, D.C.). Between each sample analysis, the cone and plate were washed with a diluted solution of haemo-sol, rinsed thoroughly with distilled water, and dried. All viscometric measurements were made in duplicate at any given shear rate, and completed within four to six minutes after the introduction of the sample to the viscometers. The error associated with the Casson viscosity measurement was \pm 2 per cent and with the yield stress determination \pm 23 per cent. In some cases, determination of plasma viscosity was also done by the capillary viscometric method, ${ }^{15}$ using pressures ranging from 10 to $15 \mathrm{~mm} . \mathrm{H}_{2} \mathrm{O}$ per $\mathrm{cm}$. tube.

\section{Calculation of Viscosity and Yield Stress}

The rheological properties of blood and plasma will be described in terms of the Casson viscosity ${ }^{16}$ and yield stress for blood and of the apparent viscosity for plasma (Figs. 1 and 2). The Casson viscosity and yield stress were determined from the plotted relationship between the ordinate scale proportional to the square root of shear stress and the abscissa scale proportional to the square root of shear rate. It has been shown that the shear stress-shear rate relationship of blood may be described by the Casson's equation: ${ }^{17}$

$$
\vee \tau=\vee C+k \vee \dot{\gamma}
$$

where $\tau$ is shear stress in dynes per $\mathrm{cm}^{2}, C$ is the yield stress in dynes per $\mathrm{cm} .{ }^{2}$, $k^{2}$ is the Casson viscosity and $\dot{\gamma}$ is the shear rate in sec. ${ }^{-1}$. The Casson equation provides a straight line plot of the shear stress-shear rate relationship and permits measurements of the yield stress as the value of the ordinate intercept at zero shear rate. ${ }^{17}$ In the present study, determination of the yield stress $(C)$ and Casson viscosity $\left(k^{2}\right)$ was made by the use of a high-speed digital computer (IBM Model 7094) in order to determine the best straight line relating values of $\vee \tau$ and $\vee \dot{\gamma}$. It was also subsequently found that the values of yield stress determined by the above method checked well with those by the direct rheogonimetric measurement. The data were analysed for statistical significance by student's $t$-test. Probability values below 0.05 were regarded as significant.

\section{Results}

Pertinent data related to the effect of cyclopropane, halothane, and methoxyflurane on the blood yield stress and the blood Casson viscosity and on the apparent viscosity of plasma are summarized in Table I. The viscosity results 


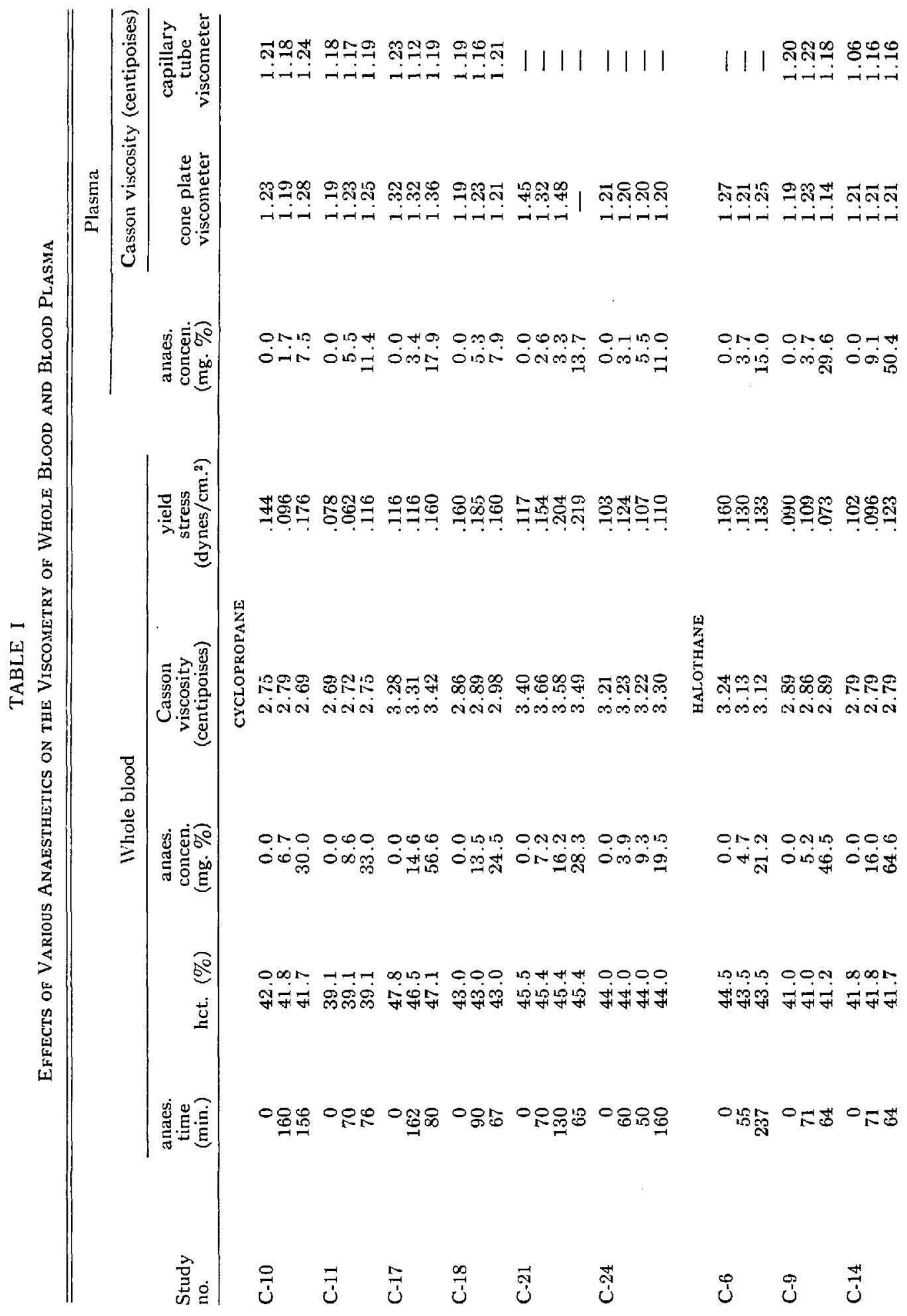




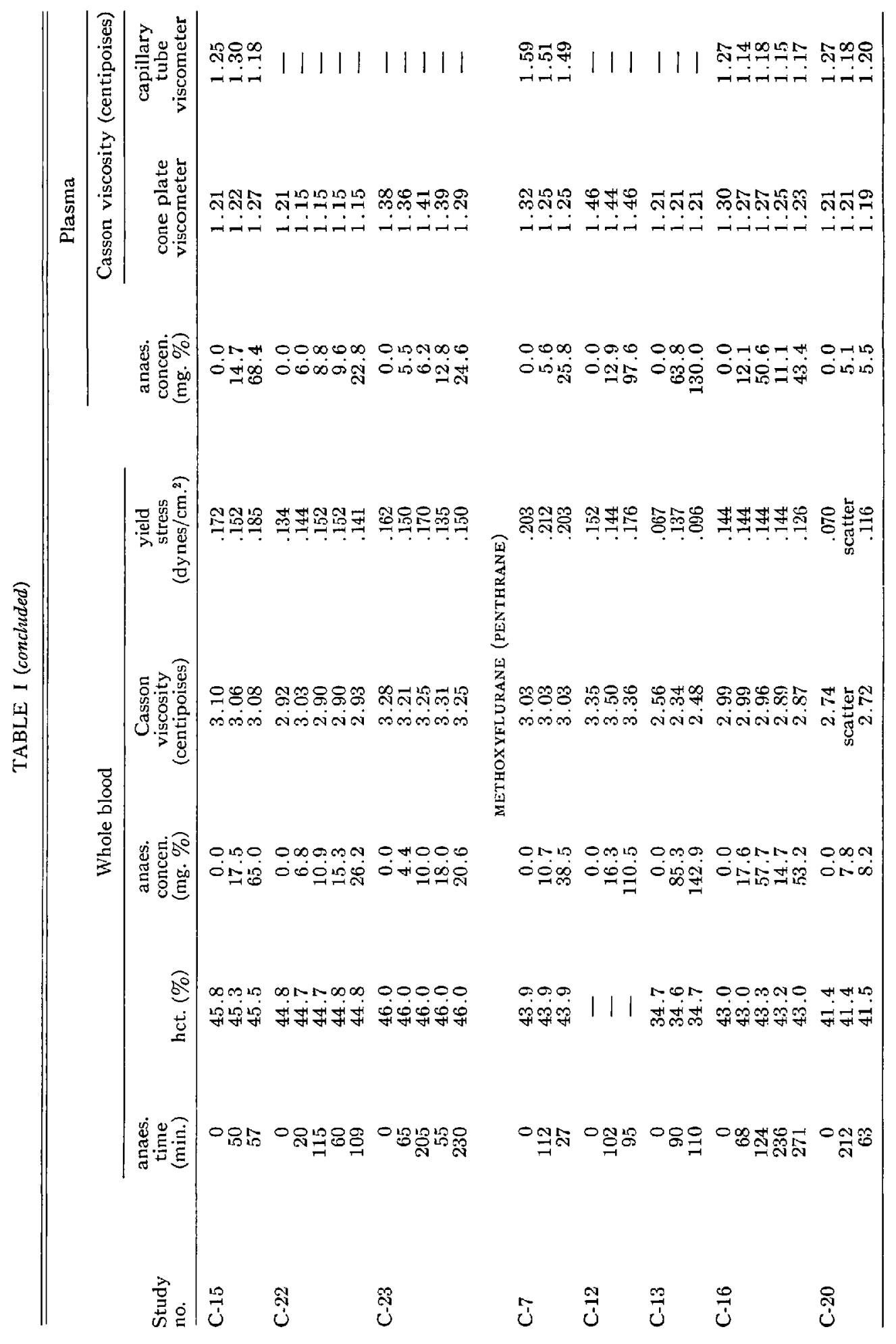


were expressed in centipoises (1/100 poise). The average values of blood gas tensions, $\mathrm{pH}$, calculated total $\mathrm{CO}_{2}$ content, and duration of exposure to anaesthetic agents are presented in Table II. Table III summarizes the mean per cent changes in the blood yield stress and Casson viscosity and mean values of haematocrit before and after the exposure of blood to the anaesthetic agents. Average changes in apparent viscosity of plasma exposed to anaesthetic agents are summarized in Table IV.

\section{Anaesthetic Concentrations in Whole Blood and Plasma Samples}

The mean concentration of cyclopropane for blood samples was $19.4 \mathrm{mg}$. per cent, ranging from 4 to $57 \mathrm{mg}$. per cent. The mean concentrations of halothane and methoxyflurane were $22.1 \mathrm{mg}$. per cent. ( 4 to $65 \mathrm{mg} . \%$ ) and $50.6 \mathrm{mg}$. per cent ( 8 to $143 \mathrm{mg} . \not 5$ ) respectively. In the present report, blood samples were arbitrarily divided into two groups as shown in the following scheme.

$\begin{array}{cccc} & \text { cyclopropane } & \text { halothane } & \text { methoxyflurane } \\ \text { Group A } & <20 \mathrm{mg} . \% & <20 \mathrm{mg} . \% & <40 \mathrm{mg} . \% \\ \text { Group B } & >20 \mathrm{mg} . \% & >20 \mathrm{mg} . \% & >40 \mathrm{mg} . \%\end{array}$

Plasma anaesthetic concentrations were generally lower than those of the respective whole blood samples. Cyclopropane retained in the plasma samples was, on the average, 36 per cent of that of whole blood. The greatest retention occurred in halothane samples (80\%).

Average retention of cyclopropane in blood samples after the viscometric procedures was 28 per cent with a Brookfield Model RVT viscometer, 44 per cent with a Brookfield Model LVT viscometer and 52 per cent with a Brookfield Model LVT $1 / 5$ viscometer of the values obtained prior to viscometry. Average changes in blood halothane concentrations with RVT, LVT and LVT 1/5 viscometers were 37,54 , and 60 per cent, respectively. Methoxyflurane retained in blood after viscometric procedures averaged 35 per cent with RVT, 65 per cent with LVT and 72 per cent with LVT $1 / 5$ viscometers. Mean changes in per cent retention of anaesthetics in plasma samples after viscometric procedures were similar to those of whole blood samples.

Haematocrit, Plasma Haemoglobin Concentration, Blood pH, Gas Tensions, and Calculated Total $\mathrm{CO}_{2}$ Content

The mean values of haematocrit before and after exposure to cyclopropane were $44.6 \pm 1.2$ and $44.6 \pm 0.7$, respectively. The haematocrit in samples before and after exposure to halothane averaged $44.0 \pm 0.9$ and $44.2 \pm 0.5$, respectively. The mean values of haematocrit before and after exposure to methoxyflurane were $40.8 \pm 2.1$ and $41.3 \pm 1.1$, respectively. The changes in haematocrit after exposure to the three anaesthetics were not significant ( $P>0.5$ for each anaesthetic). Haemoglobin concentrations in plasma increased on the average of $37.1 \mathrm{mg}$. per $100 \mathrm{ml}$. with cyclopropane, 26.2 with halothane, and $64 \mathrm{mg}$. with methoxyflurane, but these increases were no more than those obtained in control samples exposed to the gas mixture without anaesthetic agents for the same period of time. 


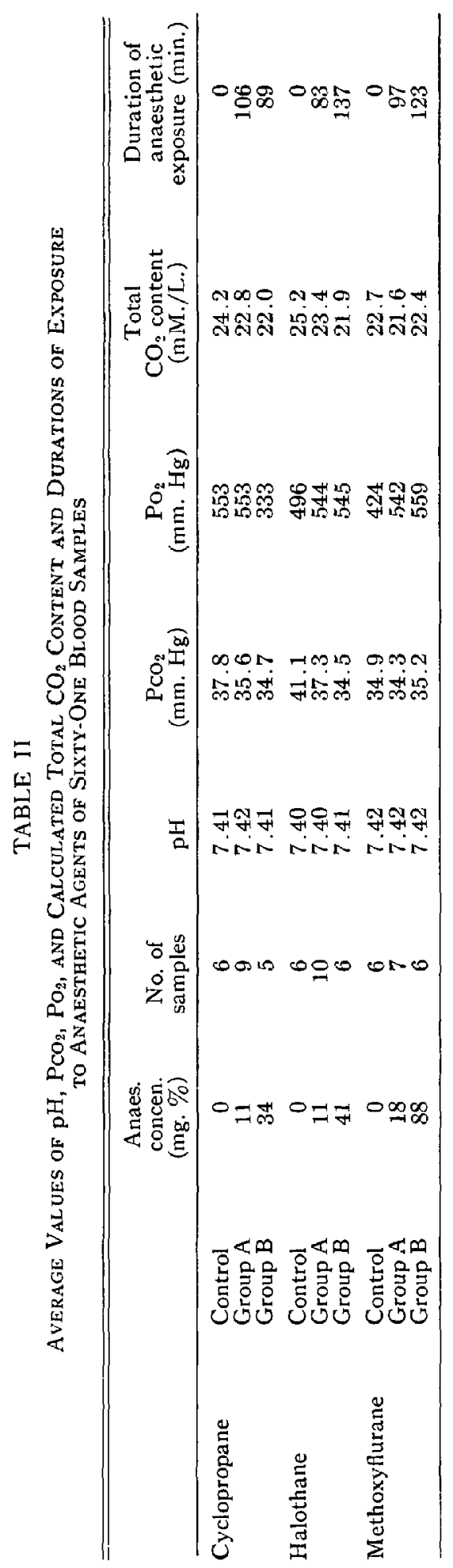


The blood $\mathrm{pH}, \mathrm{PCO}_{2}, \mathrm{Po}_{2}$ and total $\mathrm{CO}_{2}$ content in blood samples with the three anaesthetic agents were similar to those in control blood samples (Table II).

\section{Blood Yield Stress and Casson Viscosity}

With anaesthetic concentrations used clinically (group A), the changes in yield stress were +11.2 per cent with cyclopropane, -2.6 per cent with halothane, and +3.9 per cent with methoxyflurane. With anaesthetic concentrations above clinical usages (group B), the average changes in the yield stress were -2.4 per cent with halothane and +14.9 per cent with methoxyflurane (Table III). The mean change in the yield stress with cyclopropane in group B was +34.5 per cent of the control value. This change was more than the per cent error of the method related to the yield stress measurement and the statistical analysis revealed a $p$ value of less than 0.05 .

In group $A$, the average changes in the Casson viscosity were +2.5 per cent with cyclopropane, +0.5 per cent with halothane, and +0.5 per cent with methoxyflurane $(p>0.05)$. In group $B$, the mean changes in Casson viscosity were +2.3 per cent with cyclopropane, -0.3 per cent with halothane, and -2.5 per cent with methoxyflurane $(p>0.05)$.

\section{Plasma Apparent Viscosity}

Methoxyflurane resulted in a reduction of plasma viscosity on the average of 6.5 per cent $(p<0.01)$ with the capillary viscometric technique and 3 per cent $(p<0.01)$ with the cone plate viscometers. Average changes in plasma viscosity for cyclopropane and halothane were -0.6 per cent and +0.7 per cent, respectively (Table IV).

\section{Discussion}

Findings of this in vitro study indicate that under controlled conditions, cyclopropane, halothane, and methoxyflurane do not alter the viscometry of whole blood as determined by Casson viscosity. The rheological properties of blood with cyclopropane in concentrations above $20 \mathrm{mg}$. per cent resulted in an increase of blood yield stress. It has been clearly demonstrated that at any one crosssectional level of blood flowing in a vessel, there are a number of shear rates at any given lamina as a function of the distance from the vessel wall. ${ }^{6-9,17}$ The lowest shear rate occurs at the vessel wall. ${ }^{9}$ Viscosity of blood may be more precisely expressed as a profile effect of a large number of different shear rates, ranging from a higher shear rate to a lower, including zero.

Whole blood exerts a non-linear relationship between shear stress and shear rate and, therefore, the description of the rheological properties of blood requires the use of a wide range of shear rates. The advantage of the linear plot of the square root of shear stress against the square root of shear rate in determining the Casson viscosity and the yield stress is only appreciated when the shear stress of blood is measured with wide shear rate range as in the present study. The previous reports by other investigators ${ }^{10,11,18}$ are concerned only with the comparison of shear stress measured at one or a few shear rates, and are not concerned with determining the effect of anaesthetics on the yield stress value of whole blood. 


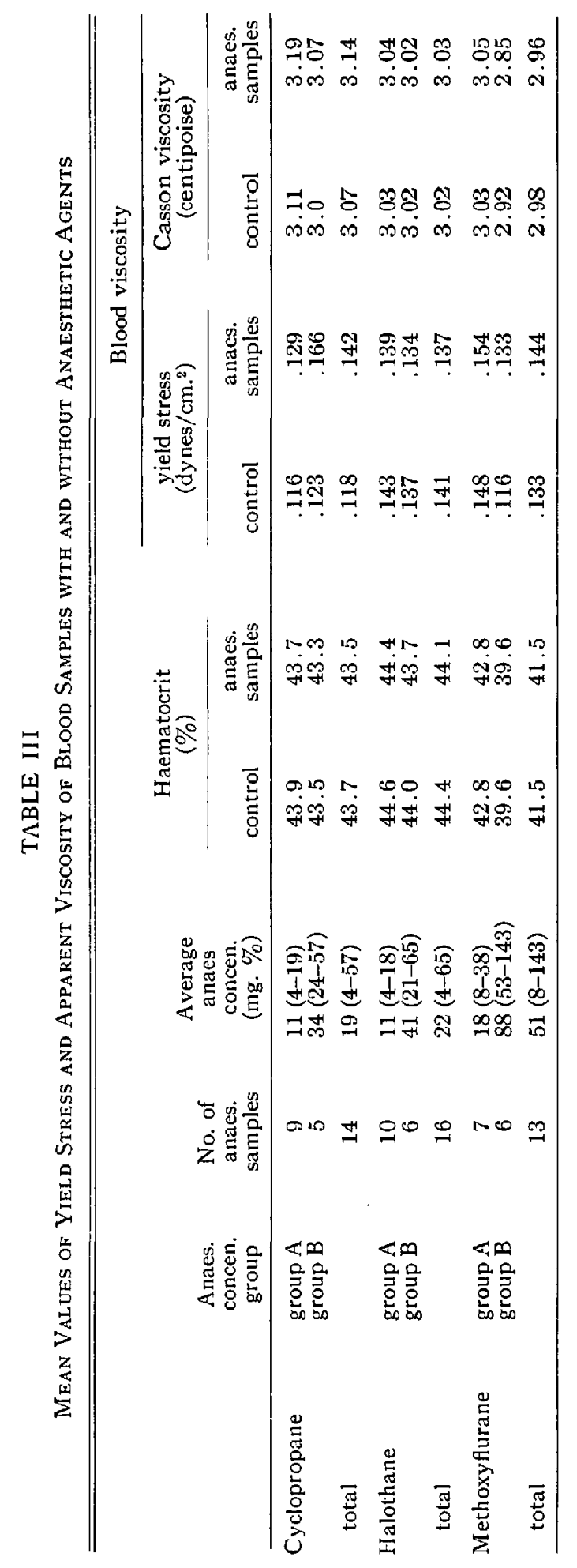


TABLE IV

Effects of Cyclopropane, Halothane, and Methoxyflurane on Mean Values of Plasma Viscosity

\begin{tabular}{|c|c|c|c|c|}
\hline & \multirow{2}{*}{$\begin{array}{l}\text { No. of } \\
\text { anaesthetic } \\
\text { samples }\end{array}$} & \multirow{2}{*}{$\begin{array}{l}\text { Anaesthetic } \\
\text { concen. } \\
\text { (mg. \%) }\end{array}$} & \multicolumn{2}{|c|}{ Viscosity (in centipoise) } \\
\hline & & & $\begin{array}{r}\text { control } \\
\text { samples }\end{array}$ & $\begin{array}{l}\text { anaesthetic } \\
\text { samples }\end{array}$ \\
\hline $\begin{array}{l}\text { Cyclopropane } \\
\text { (i) capillary tube } \\
\text { (ii) Brookfield viscometer }\end{array}$ & $\begin{array}{r}8 \\
13\end{array}$ & $\begin{array}{l}8(1.7 \sim 17.9) \\
7(1.7 \sim 17.9)\end{array}$ & $\begin{array}{l}1.20 \\
1.26\end{array}$ & $\begin{array}{l}1.18 \\
1.27\end{array}$ \\
\hline total & 21 & $7(1.7 \sim 17.9)$ & 1.23 & 1.22 \\
\hline $\begin{array}{l}\text { Halothane } \\
\text { (i) capillary tube } \\
\text { (ii) Brookfield viscometer }\end{array}$ & $\begin{array}{r}6 \\
16\end{array}$ & $\begin{array}{l}29(3.7 \sim 68.4) \\
18(3.7 \sim 68.4)\end{array}$ & $\begin{array}{l}1.17 \\
1.24\end{array}$ & $\begin{array}{l}1.20 \\
1.23\end{array}$ \\
\hline total & 22 & $21(3.7 \sim 68.4)$ & 1.21 & 1.21 \\
\hline $\begin{array}{l}\text { Methoxyflurane } \\
\text { (i) capillary tube } \\
\text { (ii) Brookfield viscometer }\end{array}$ & $\begin{array}{r}8 \\
14\end{array}$ & $\begin{array}{l}20(5.1 \sim 50.6) \\
39(5.1 \sim 130.0)\end{array}$ & $\begin{array}{l}1.38 \\
1.34\end{array}$ & $\begin{array}{l}1.28 \\
1.30\end{array}$ \\
\hline total & 22 & $32(5.1 \sim 130.0)$ & 1.36 & 1.29 \\
\hline
\end{tabular}

Albert et al., ${ }^{10}$ using a capillary-type viscometer, reported that halothane and thiopental sodium reduce blood viscosity, whereas cyclopropane increases it. However, it should be realized that the use of the capillary tube viscometry method should be limited to the determination of apparent viscosity in a Newtonian fluid such as plasma.

Our data of the unaltered blood viscosity with wide concentrations of methoxyflurane, halothane, and cyclopropane were related to shear rates ranging from 1500 to 6.75 per second. When the blood was exposed to clinical concentrations of cyclopropane and to all concentrations of halothane and methoxyflurane, it was found that values of yield stress were unchanged. A small increase in mean yield stress value was observed in blood exposed to higher concentrations of cyclopropane.

The yield stress values may change without parallel changes in apparent viscosities of either blood or plasma at the higher shear rate range, and the yield stress and apparent viscosity may change in opposite directions. Thus, it is important to note that both the mean Casson viscosity and the mean yield stress values of whole blood samples were increased only with cyclopropane. These small increases in yield stress observed in this study, in fact, might be of physiological importance because, in the smallest tapered peripheral blood vessels (e.g. with a diameter of 30 microns), the wall shear rates will be in the order of magnitude of the blood yield stress.

Recently, the importance of the relationship between the process of erythrocyte aggregation and the rheological effect of any agent capable of altering cell aggregations in vivo has been pointed out. ${ }^{5}$ Since estimated capacity of the microcirculation reveals that most of the circulating blood is contained in the microvasculature with an internal diameter of 100 microns or less, the significant 
pressure drop occurs within this microcirculation. Therefore, it is reasonable to state that any changes in the rheological properties of blood may result in alterations of blood flow in the microcirculation. The marginal increase of blood yield stress observed with high concentrations of cyclopropane may indicate the resultant decrease in blood flow within the microvasculature.

The variables and interrelated factors of surgery that could alter blood viscosity during clinical anaesthesia were eliminated in this study by conducting in vitro investigations on human blood. The unchanged values of blood $\mathrm{pH}$ and gas tensions and of haematocrit in the blood samples with anaesthetics indicate that the rheological properties measured in the present study were not confounded by these factors. The use of heparin as the anticoagulant in our study also eliminated the possible effect on viscometry by other anticoagulants, such as potassium oxalate. ${ }^{18}$

Changes occurring in blood viscosity and yield stress due to anaesthetic agents in vitro may not fully describe in vivo blood viscometry changes during surgery because other rheologic properties may be altered, i.e., fibrinogen concentration, haematocrit, electrolytes, or electrical charges of the red blood cells and the plasma proteins. Our in vitro study indicates that, while no distinct changes in blood or plasma viscosity or yield stress occurred with the use of wide clinical concentration ranges of halothane, cyclopropane, and methoxyflurane, there did appear to be a marginal decrease in plasma viscosity with methoxyflurane and a marginal increase in blood yield stress with concentration of cyclopropane above the clinical range.

\section{SUMmaRY}

Cyclopropane, halothane, and methoxyflurane were investigated for their effects on the viscometry of freshly drawn human blood (group $\mathrm{O}, \mathrm{Rh}^{+}$). A total of 43 blood and 63 plasma samples containing specific anaesthetic agents were studied under controlled conditions of temperature, $\mathrm{pH}, \mathrm{PCO}_{2}, \mathrm{Po}_{2}$, and red blood cell and plasma protein concentrations. A series of three cone plate viscometers, each with different shear rate ranges from 1500 to $6.75 \mathrm{sec}^{-1}$, was used. The Casson viscosity of blood and apparent plasma viscosity were determined from the slope of the shear stress-shear rate relationship plotted on a square root scale. Yield stress was determined by extrapolation from the shear stress axis intercept. Our findings indicate that the three anaesthetic agents, within concentrations equivalent to those used during clinical anaesthesia, caused no discernible effect on either yield stress or the apparent viscosity of blood or plasma. However, there was a marginal increase of the yield stress of blood with high concentrations of cyclopropane (above $20 \mathrm{mg} . \%$ ) and a trend toward reduced plasma viscosity in all of the methoxyflurane samples.

\section{RÉSUMÉ}

Nous avons étudié les effets du cyclopropane, de l'halothane et du méthoxyflurane sur la viscométrie du sang humain fraichement prélevé (groupe $O, R h$ 
positif). Nous avons fait nos études sur quarante-trois échantillons de sang et soixante-trois échantillons de plasma contenant spécifiquement ces agents anesthésiques; l'étude a été faite aux mêmes conditions de température, de $\mathrm{pH}$, de $\mathrm{PCO}_{2}$ et de concentration en protéines des globules rouges et du plasma.

Nous avons fait des séries de trois viscomètres cone-plate, chacun possédant différentes échelles "shear rate" de $1500-6.75 \mathrm{sec}^{-1}$. Nous avons précisé la viscosité Casson du sang et la viscosité apparente du plasma à partir de la courbe de relation "shear stress-shear rate" placée sur une échelle de racine carrée. Le "yield stress" a été obtenu par l'extrapolation à partir du croisement de l'axe du "shear stress".

Nos résultats nous apprennent que, à des concentrations équivalentes à celles utilisées en anesthésie clinique, ces trois agents anesthésiques ne produisent aucun effet décelable ni sur le "yield stress" ni sur la viscosité apparente du sang ou du plasma. Toutefois, avec une haute concentration sanguine de cyclopropane (au-dessus de $20 \mathrm{mg} . \not{\%}$ ), nous avons observé une faible augmentation du "yield stress" du sang; de plus, dans tous les échantillons avec le méthoxyflurane, nous avons observé une tendance à la diminution de la viscosité du plasma.

\section{ACKNOWLEDGMENTS}

The authors acknowledge the technical assistance of Mr. Hans Laasberg, Ch.E.

\section{REFERENCES}

1. Charm, S.; McCornis, W.; Tejada, C.; \& Kurland, G. Effect of a Fatty Meal on Whole Blood Viscosity. J. Appl. Physiol. 18: 1217 (1963).

2. Hannes, R. H. \& Burton, A. C. Role of the Non-Newtonian Behavior of Blood in Hemodynamics. Am. J. Physiol. 197: 943 (1959).

3. Mayer, G. A. Blood Viscosity in Healthy Subjects and Patients with Coronary Heart Disease. Canad. M. A. J. $91: 951$ (1964).

4. Merrill, E. W.; Gilliland, E. R.; Cokelet, G.; Shin, H.; Bhutten, A.; \& Wells, R. E., JR. Rheology of Blood and Flow in the Microcirculation. J. Appl. Physiol. 18: 255 (1963).

5. Wells, R. E., JR. Rheology of Blood in the Microvasculature. New England J. Med. 270: 832, 889 (1964).

6. Poiseuille, J. L. M. Recherches experimentales sur le mouvement des liquides dans le tubes de tres petits diametres. Compt. rend. acad. sc., 2: 961, 1041 (1840).

7. Hacenbach, E. Ueber die Bestimmung der Zähigkeit einer Flussigkeit durch den Ausfluss aus Rohren. Pogg. Ann. 109: 385 (1860).

8. Merrill, E. W.; Cokelet, G.; Brutten, A.; \& Wells, R. E., Jr. Non-Newtonian Rheology of Human Blood-Effect of Fibrinogen Deduced by "Subtraction." Circulation Res. 13: 48 (1963).

9. Dintenfass, L. Thixotropy of Blood at Very Low Rates of Shear. Kolloid Ztschr. 180: 160 (1962).

10. Albert, S. N.; Jain, S. C.; \& Shadm, J. N. Studies on Blood Viscosity and Its Significance in Anesthesia. Med. Ann. D.C. 33: 372 (1964).

11. Behar, M. G. \& Alexander, S. C. In Vitro Effects of Inhalational Anesthetics on Viscosity of Human Blood, Anesthesiology. 27: 567 (1966).

12. LaAsberg, L. H. \& Etsten, B. E. Gas Chromatographic Analysis of Cyclopropane in Whole Blood. Anesthesiology. 26: 216 (1965).

13. ZijLstra, W. G. \& VAN KaMpen, E. J. Standardization of Hemoglobinometry: Preparation and Use of a Stable Hemoglobincyanide Standard. Clin. chim. acta. 7: 96 (1962). 
14. Welis, R. E.; Denton, R.; \& Merrill, E. W. Measurement of Viscosity of Biologic Fluids by Cone Plate Viscometer. J. Lab. Clin. Med. 57: 646 (1961).

15. Fahraeus, R. \& LindQvist, T. Viscosity of Blood in Narrow Capillary Tubes. Am. J. Physiol. 96: 562 (1931).

16. Casson, N. Flow Equation for Pigment-Oil Suspensions of the Printing Ink Type. Chap. 5 in Rheology of Disperse System. Ed. C. C. Mills. London: Pergamon Press (1959), p. 4.

17. Charm, S. \& Kunland, G. Viscometry of Human Blood for Shear Rates of 0-100,000 sec. -1 . Nature. 206: 617 (1965).

18. Boyan, C. P.; Underwood, S.; \& Howland, W. S. The Effects of Operation, Anesthesia and Plasma Expanders on Blood Viscosity. Anesthesiology. 27: 279 (1966).

19. MAYER, G. A. \& KIss, O. Blood Viscosity and In Vitro Anticoagulants. Am. J. Physiol. 208: 795 (1965). 